\title{
DECODING LATE ROMAN LAW
}

\author{
By A. D. LEE
}

\begin{abstract}
J. HARRIES, LAW AND EMPIRE IN LATE ANTIQUITY. Cambridge: Cambridge University Press, I 999. Pp. ix +235. ISBN 0-52 I-4IO87-8. £37.50.

T. HONORÉ, LAW IN THE CRISIS OF EMPIRE, 379-455 AD: THE THEODOSIAN D YNASTY AND ITS QUAESTORS WITH A PALINGENESIA OF LAWS OF THE DYNASTY. Oxford: Clarendon Press, 1998. Pp. xiii + 320, 2 disks. ISBN 0-I 9-826078-4. £45.00.

J. F. MATTHEWS, LAYING DOWN THE LAW: A STUDY OF THE THEODOSIAN CODE. New Haven and London: Yale University Press, 2000. Pp. xv+3I4. ISBN 0-300-07900-1. US\$40.00.
\end{abstract}

Who was the longest reigning Roman emperor? Perhaps somewhat surprisingly, the answer is not one of the more obvious potential candidates - Augustus, Constantine, Justinian - but Theodosius II, whose official tenure of the imperial office lasted nearly half a century (A.D. 402-50). ${ }^{1}$ Why then does his name not feature more prominently in most people's mental landscape of Roman imperial history? It is of course partly because the fifth century is generally less familiar territory, but also because the sources for Theodosius' life leave an impression of a roi fainéant, of a relatively unassertive individual who was more interested in scholarly pursuits and personal piety than in exercising political power; Edward Gibbon went so far as to write of 'the vacant throne of 'Theodosius' and to insinuate that he effectively remained a minor throughout his time as emperor. ${ }^{2}$ Despite this, his reign was not without its achievements, though it is a moot point to what extent they can be attributed to him personally. ${ }^{3}$ Arguably the most significant was the compilation of imperial laws promulgated under his name in A.D. $43^{8}$ - the Codex Theodosianus. This substantial work, the result of nearly nine years' labour by an initial team of nine commissioners expanded to sixteen in the final two years, brought together (in abbreviated form) imperial laws from the reign of Constantine until the year 437. In its immediate context, its successful completion represents a very considerable organizational feat, while at a practical level it must have simplified greatly the day-to-day work of judges and lawyers. From a longer perspective, the Theodosian Code occupies a critical place in the development of European law - it formed the basis of law codes in a number of the Germanic successor states in the early medieval West, but, even more importantly, it 'spurred Justinian to outdo his predecessor; and without Justinian Europe would neither have acquired nor transmitted to the rest of the world its unique legal-political culture' (Honoré, I28). Finally, as has long been appreciated, the Code is a fabulous resource on all manner of subjects for modern historians of Late Antiquity.

Given its wide-ranging significance, it should occasion no surprise that the Theodosian Code constitutes a central point of reference for the three important and very different books on late Roman law reviewed here (differences which are all the more intriguing given the long association of all three authors with Oxford and indeed with one another). John Matthews' study, with its deliciously punning title, focuses most closely on the Code, concerned as it is to elucidate the multifarious problems raised by the attempt to understand in detail how the Code came into being. This leads him into a close investigation of the Code's sources and of its textual history. By his own admission, some of the latter is a distillation of Theodor Mommsen's Prolegomena to his edition of the Code, but that in itself is of considerable value, especially for those whose

\footnotetext{
${ }^{1}$ Born on ro April 401 , Theodosius was proclaimed Augustus on 10 January 402 , though he only became sole emperor in the East upon the death of his father Arcadius on 1 May 408 ; he died on 28 July 450 as the result of a fall from his horse while hunting (references in PLRE 2, s.r. Theodosius 6).
}

\footnotetext{
${ }^{2}$ E. Gibbon, The Decline and Fall of the Roman Empire, ch. 32 (ed. D. Womersley, 1994, vol. 2, 262-3).

${ }^{3}$ For a succinct overview of Theodosius' reign, with references to further literature, see now $C A H$ XIV (2000), 34-42.
} 
Latin and/or eyesight may not be up to deciphering the minuscule text of Mommsen's original. ${ }^{4}$ Neither, however, is he afraid to take issue with the master, notably (here following the lead of Paul Krüger) over Mommsen's decision to exclude material in the Codex Fustinianus from his reconstruction of the text of the lacunose first five books of the Theodosian Code. The chapters in which these matters are tackled are often highly technical, but they are balanced by chapters of broader historical interest, and, as Matthews argues, if the Code is to be used as historical evidence, historians must ask of it the same questions they would of any historical source - 'what sort of text it is, who wrote it for whom, with what purpose or agenda, and how it was received' (280).

Tony Honore's subject is the individuals who held the office of quaestor during the Theodosian dynasty - that is, the official most closely associated with the drafting of legislation in Late Antiquity. In ten of his thirteen chapters he employs the now familiar and controversial technique of stylometric analysis which he used in Tribonian (1978) (review by Averil Cameron, $\mathscr{F} R S 69$ (1 979), I 99-201) and Emperors and Lawyers (1981; revised edn I 994) (review by F. Millar, $\mathscr{F} R S 76$ ( 1986$), 272-80$ ) with a view to separating out the quaestors of the Theodosian period and, where possible, identifying them. However, this analysis is seen at least partly as a stepping stone towards explaining the genesis and realization of the Code (ch. 6), as well as exploring other even larger issues concerning the survival of the Eastern Empire and demise of the West during the fifth century (ch. I) ${ }^{5}$

Jill Harries' wide-ranging book is essentially a sequence of studies of late Roman law in action, and so focuses less explicitly on the Code. She investigates the formulation of laws (chs 2-3), their enforcement (ch. 4) and application in the courts (chs 5-8), as well as alternative means of handling legal disputes (chs $9-10$ ). Her determination to place these subjects in their wider political and social context means that her study is of relevance and interest well beyond the field of legal history in its strict sense. Nevertheless, the Theodosian Code is necessarily ever present, for despite the broad chronological parameters implied by its title, this study rarely ventures into the sixth century and certainly makes no use of that underexploited treasure trove for the interaction of law and late Roman political and social life, Justinian's Novels (nor, sadly, is this one of the future projects earmarked in her preface); as she makes clear at the outset, this study's main focus is the period from Diocletian to Theodosius II, 'thus giving a central role to the Code of 'Theodosius' (vii).

All three authors have already made significant contributions to the study of late Roman law in its historical context in recent years. Harries has published an important

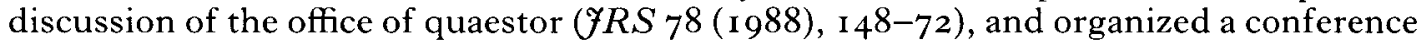
which resulted in an invaluable collection of essays (J. Harries and I. Wood (eds), The Theodosian Code: Studies in the Imperial Law of Late Antiquity (I993) (review by C. Kelly, $\mathcal{F R S} 86$ ( 1996$), 235-7)$ ). This volume included a notable paper by Matthews in which he sketched out a number of the arguments developed in detail in the volume under review, as well as one by Honoré on the quaestors of Theodosius II (a revised version of which has become ch. 5 of the study reviewed here); Honore has also produced a major article on 'The making of the Theodosian Code' (ZSS I03 (1986), I33-222). There has, then, been opportunity for cross-fertilization of ideas (Harries also had access to Honorés book when making final revisions to hers, and Matthews had access to both of the others at a comparable stage with his), but it is equally clear that all three studies, with long periods of gestation reaching back into the I 980 , have quite different aims.

In what follows, I propose to focus on those issues raised by these books which strike me as particularly important and where these studies intersect with one another

\footnotetext{
${ }^{4}$ Some of Matthews' page references to Mommen's Prolegomena require emendation: at p. I 9 n. 27 and p. 30 n. 68 , xi should be ix, while the nonsense page reference at p. 103 n. 44 (xcvvvi) should of course be xcviii - good illustrations of the sort of errors of transmission which beset the text of the Theodosian Code itself.
}

${ }^{5} \mathrm{Ch} .9$, on the legal interests of the author of the Historia Augusta (a revised version of a previous paper), seems peripheral to the volume's central themes. 
to varying degrees, whether by way of mutual illumination or (sometimes) disagreement: first, the inception and realization of the Code itself; secondly, aspects of the legal process it embodies in action during Late Antiquity; and finally, the relationship of Christianity to the Code and to late Roman law more generally. In doing so, I write as an historian rather than a lawyer, but this is not inappropriate given that two of the authors (Matthews and Harries) are also historians and have written what are clearly historical studies, while the third, though first and foremost a lawyer, seeks to derive conclusions of an historical nature from his analyses.

\section{THE THEODOSIAN CODE: GENESIS AND REALIZATION}

Why was the decision taken in A.D. 429 to initiate the compilation of the Code? As these studies appreciate, this is a question which has to be tackled from a variety of angles. Practical utility was certainly a prime consideration. Elimination of ambiguity and confusion, and their replacement with brevity and clarity - these are the themes of the various laws which set the project in motion and brought it to completion, signalling a concern to assist lawyers and judges struggling to keep abreast of the imperial laws which had steadily proliferated during the preceding century (Honoré, i 27-8; Harries, 59-60; Matthews, I9-2 I). One feature of the Code, however, seems to run counter to this aim - its inclusion of laws superseded by subsequent legislation. This was not simply the result of sloppy work by the commissioners - it was part of the original specification in 429, which stated that the Code was being "composed for more diligent men (diligentiores), to whose scholarly efforts (scholasticae intentioni) it is granted to know those laws also which have been consigned to silence' (CTh I.I.5, trans. Pharr). Like many previous scholars, Harries interprets this as a concession to the antiquarian interests of experts in legal history, reflecting Theodosius' own scholarly inclinations $(22,52) .{ }^{6}$ Honore $(147)$ and Matthews $(57-8)$ both allow this view some force, but they also accept the argument that scholastica intentio is better translated here as something like 'lawyerly attention' (W. Turpin, ZSS r 04 ( 1987 ), 62 I) and that the retention of obsolete laws could also serve practical ends: 'past laws are used to help interpret present laws [and] it would have been awkward to separate the parts of earlier laws that were repealed ... from those that were not' (Honoré, I 44-5). It is surely also relevant that only one of the commissioners on each of the successive panels was an 'academic lawyer' (Matthews' phrase (8I), used of Apelles and Erotius).

Why did this longstanding need for greater simplicity and clarity only result in action during the reign of Theodosius? Part of the answer lies in the impetus provided by political circumstances, specifically the deterioration of relations between East and West during the early decades of the fifth century, and the determination in Constantinople after the death of the western emperor Honorius in A.D. 423 to re-establish closer ties. Matthews' opening chapter (which in some respects picks up where his Western Aristocracies and Imperial Court (1975) left off) places the Code, with its emphasis on unity through its provision for the validity of Eastern laws in the West and vice versa, in the context of Constantinople's role in installing Valentinian III on the Western throne in A.D. 425 and his marriage to 'Theodosius' daughter in A.D. 437 (cf. Honoré, 97, I 29 and $Z S S$ I03 (1986), I76-81; Harries, 37,62). The importance and relevance of this theme finds further support in the final version of the Notitia Dignitatum, persuasively presented in a recent discussion as a document (perhaps emanating from the circle of Valentinian's mother, Galla Placidia) whose purpose was primarily ideological namely to 'underscore the unity of the whole empire and the relatively symmetrical nature of the two administrations' ${ }^{7}$ Harries makes explicit an additional dimension of

\footnotetext{
${ }^{6} \mathrm{cf}$. her more detailed argument on this point in 'Pius princeps: Theodosius II and fifth-century Constantinople', in P. Magdalino (ed.), New Constantines: The Rhythm of Imperial Renewal in Byzantium, 4 th-1 3 th Centuries (1994), 35-44, at $4 \mathrm{I}-3$.
}

7 P. Brennan, 'The Notitia Dignitatum', in C. Nicolet (ed.), Les Litteratures techniques dans l'antiquité romaine, Entretiens Hardt vol. 42 (1996), 153-69, at I 68 . 
this scenario - that the Code was at the same time a way of reinforcing eastern ascendancy (37; cf. Harries and Wood, The Theodosian Code, 16 ).

Another part of the answer to the question of timing lies in the availability of the requisite expertise. Matthews addresses this in terms of 'the vigor and high profile of legal studies in the generations preceding the commissioning of the Theodosian Code' (2 I), particularly emphasizing (contrary to what one might have expected) the high quality of Roman jurisprudence in the eastern Mediterranean. Honoré adds to this a more specific argument about the holders of the office of quaestor during the Theodosian dynasty, based on stylometric analysis of the laws of this period. The caveats with which he hedges his analysis are sometimes such as to make one wonder whether the analysis can yield any firm conclusions, but there is, I think, reason to accept at least some of his inferences. It has been observed that 'Honore's method works best with substantial quantities of textual material' (S. Corcoran, The Empire of the Tetrarchs (1994), 78), and he is dealing here with at least fifty per cent more text over a timespan about a third shorter compared with Emperors and Lawyers. In my view, the real value of his analysis lies not primarily in his attempts to match up blocks of laws with known quaestors, though this process does incidentally lead, e.g., to useful discussions of the administrations of Eutropius (8z-3) and of Valentinian III (258-63); rather it is in his endeavouring to determine how many quaestors in this period were lawyers by training (for although quaestors had a key role in the drafting of legislation, legal training was not a requirement of the post). This involves close attention to the extent to which blocks of laws show familiarity or otherwise with technical legal terminology and the finer points of the law. Sceptics may be tempted to argue that the presence of these markers could equally well be the work of the quaestor's legally-trained subordinates, but they must then explain the considerable variations in usage across time. Honore's conclusion is that during the course of the Theodosian dynasty there was an increasing number of eastern quaestors who were also lawyers - a pattern whose identification significantly enhances our understanding of why the Code was compiled when it was.

Honoré's argument also bears on a final issue relating to the inception of the Code - who actually initiated it? This is a question which necessarily cannot be answered in a definitive manner, but the fact that the final product bore Theodosius' name certainly does not prove that Theodosius instigated it. Not surprisingly, Honore argues that Theodosius' lawyer-quaestors took the key role in initiating the project (97, 123), and, if that was the case, then one can well imagine them persuading Theodosius to endorse the project by dangling the prospect of its bearing and immortalizing his name. Honoré's position finds support in Harries' observation that 'the act of codification was in fact one of several by which the imperial bureaucracy asserted the rule of law over the rule of the emperor' $(42)$.

The process of producing the Code between A.D. 429 and 437 also raises a number of contentious issues. One concerns the significance of the law of A.D. 435 (CTh I.1.6) which established a second, enlarged panel of commissioners and gave further instruction on editorial procedures. Many scholars, including Mommsen, have thought that this marked an abandonment of the original plan of 429. All three books agree in firmly rejecting this idea, though the different terms they use to describe the significance of the law of 435 contain important nuances - 'modification' (Honoré, 125, Harries, 64) and 'refinement' (Harries, 23) are not quite the same as 'clarification' in response to 'queries raised by the editors' (Matthews, 70), and it is Matthews' full and careful discussion of the issue (59-7 I) which is ultimately persuasive.

A second important issue concerns the sources of the laws which the commissioners included in the Code. One possibility is that they used central archives in the imperial capitals, another is that they used local sources in the provinces. As Matthews observes, the answer 'lies neither at one extreme nor at the other, but in some proportion across the whole range of possibilities between them' (283). In the early twentieth century, Otto Seeck emphasized the role of provincial sources, while more recently Boudewijn Sirks has championed the primacy of central archives (in Harries and Wood, The Theodosian Code, ch. 2). Developing in considerable detail the arguments he rehearsed in that same volume - indeed, this is one of the chief burdens of his book - Matthews 
presents a very strong case for greater use of non-metropolitan sources for fourthcentury laws than Sirks has been prepared to allow. This involves a great deal of painstaking dissection of the evidence in which he demonstrates that the text of the Code, sometimes in combination with other material, whether legal or epigraphic, can be made to yield up more of relevance to this issue than seemed possible. His detailed arguments necessarily do not always make for easy reading and are difficult to summarize in a few lines, but they are presented with exemplary clarity (leavened with wry humour wherever possible) and are lucidly drawn together in the concluding chapter. As for the other two books, Harries effectively reserves her judgement (23), though she might have been less inclined to do so had she been in a position to read Matthews' fuller arguments, while Honoré argues that about twenty per cent of eastern laws derived from provincial sources until A.D. 398 and a similar proportion of western laws until about A.D. 4I 8, after which they were drawn almost exclusively from imperial centres $\left(1_{3} 6-41\right)$. This gives a greater role to provincial sources than Sirks concedes, though not, I suspect, as much as Matthews would; the latter, however, does not engage in quantification to the same degree as Honoré, giving due weight to the impossibility of attaining a definitive solution and so preferring to talk in terms of 'defin[ing] the possibilities of an answer' (284).

One might have expected the final stage in the process of the Code's production its actual promulgation - to be a matter of minimal interest, were it not for the fact that there has been preserved a substantial record of this event for the western half of the Empire, at a meeting of the Senate in Rome. This record, the so-called Gesta Senatus, which provides invaluable insights into many matters of broader interest, is the subject of a whole chapter (3) in Matthews' study. A striking feature of the Gesta is the acclamations - an important medium in Late Antiquity for the expression of the views of a group, in this case directed in a highly laudatory tone by the senators towards the emperors and senior imperial officials. These seem alien to modern Western sensibilities because of their apparently excessive flattery and because of the extraordinary number of times the same phrase was chanted - twenty-eight times in some cases. Matthews, however, demonstrates the relevance of some of them to understanding the mechanisms by which the commissioners hoped to ensure the dissemination of accurate copies of the Code. Harries also discusses the Gesta as part of a chapter (3) on 'The Construction of Authority', observing that the occasion 'on the whole, reinforced the imperial autocracy and the authority of the emperors' laws' (66), while also noting its implicit recognition of the importance of senatorial consent and the apparent way in which the Senate seized the opportunity to re-assert some of its privileges. For Matthews, the occasion was too highly orchestrated for this to have been possible, but his suggestion concerning the interpretation of the final acclamation (48), while amusing, is on balance the less plausible reading.

The Code that was promulgated in A.D. 438 was certainly a remarkable achievement, but it was also only the first stage of a larger project which was, however, never fully realized. As envisaged in A.D. 429, the compilation of abbreviated imperial laws from Constantine to Theodosius was then to have been combined with the earlier codes of Gregorius and Hermogenianus, produced under Diocletian, and with the writings of the jurists, to produce a definitive code of Roman law, and it was this final code which was to bear Theodosius' name (CTh 1.I.5 [11.14-17]). It is possible that it was still the intention in A.D. 438 to proceed to this second, even more ambitious stage (which, a little confusingly, Harries (64) talks of in terms of three stages) - certainly, the original law of 429 which established the commission and its terms was read out again at the official promulgation of the Code in 438 (as noted by Harries, 22). If so, then one probably has to think in terms of the second stage being derailed by a variety of contingent circumstances - the impact of the Vandals, Attila, and the ongoing Christological controversies of the 440s. However, the fact that Theodosius' name was now given to the first of the two planned codes looks like a tacit acknowledgement that the second stage was a bridge too far (Honoré talks of postponement (I 26)). Perhaps the experience of producing the first code, and the amount of time it had consumed, instilled in the commissioners a heightened sense of realism; after all, even Justinian and his able team 
of lawyers a century later did not attempt anything quite so grandiose as the full Theodosian plan.

\section{LATE ROMAN LAW IN ACTION}

A fundamental issue for the operation of any legal system is the impact and effectiveness of legislation, and its implementation by the courts. This is one of the central preoccupations of Harries' book, pursued along a variety of avenues. In ch. 4 ('The Efficacy of the Law') she argues persuasively for a more differentiated approach to the subject of enforcement of and obedience to laws, pointing out, for example, that in the large area of private law "a Roman citizen did not choose to "obey" or "disobey" the relevant laws, but whether or not to invoke them in his or own self-interest' (8I; cf. Honore, 26). She gives particular attention to a feature of the Theodosian Code which has frequently been regarded as demonstrating the ineffectiveness of late Roman legislation - namely, the widespread repetition of laws. As she observes (and documents), laws were often repeated in Late Antiquity for a variety of reasons other than ineffectiveness: because there seems to have been a belief that recently issued laws were more effective than older ones; because of requests for adjudication on similar issues from different parts of the Empire; because emperors wanted to provide reassurance to subjects uncertain about the law on a particular issue $(82-8$; $\mathrm{cf}$. Honoré, $25-6$, I $33-4)$. This provides a salutary corrective to longstanding views, though I would feel more comfortable if the conclusion that 'repeated laws were laws that worked' (2 I 2 ) had included a qualifying 'usually' or 'more often than not'; after all, the law adduced on the point that recent laws carry more weight ( $N$ Val 6. I pr.) also talks quite explicitly about this particular law having to be issued because of continued disregard for previous laws on the same subject (viz., army recruits and deserters). Her discussion of the enforcement of religious prohibitions also rather downplays the problem of uncooperative local officials, a phenomenon recently and fruitfully discussed by Scott Bradbury. ${ }^{8}$

Ch. 7 of Matthews' book ('Delivering the Law') also gives some consideration, albeit more obliquely, to the issue of the impact of law in the course of a wide-ranging discussion of general interest which reconstructs the 'life history' of an imperial law, from conception through to promulgation in the cities and towns of the provinces. As he notes, 'the impact of Roman legislation owed its force - and the legislation its validity - to its promulgation and display in the communities to which it was sent' ( 187 ). His discussion of the evidence for this final stage of this process ( $187-99$ ) provides fascinating insights into the practicalities of how documents emanating from the imperial court actually made their presence felt at the local level. It also hints at another critical issue - what this presupposes about the extent of literacy in the provinces without exploring the implications (which he may well justifiably have regarded as straying too far from his remit, though a recent conference paper, on which some of this chapter is closely based, does expand on the subject a little further ${ }^{9}$ ). If one were to pursue this more systematically in the late Roman context, however, then one would want to take account of the evidence concerning the town of Edessa, in the eastern province of Osrhoene, in an invaluable contemporary source from the early sixth century, the Syriac Chronicle attributed to Joshua the Stylite. ${ }^{10}$ Its reporting of major events in the life of Edessa during one five-year period includes mention of the arrival of three imperial laws (chs $3 \mathrm{I}, 34,46$ ), the intriguing decision of the local governor to set

\footnotetext{
8 'Constantine and the problem of anti-pagan legislation in the fourth century', $C P h 89$ (1994), 120-39, at $132-9$.

9 'Eternity in perishable materials: law-making and literate communication in the Roman Empire', in T. W. Hillard et al. (eds), Ancient History in a Modern University (1 998), vol. 2, 253-65.
} 10 Now once again readily accessible, in a new
translation with commentary by F. R. Trombley and
J. W. Watt, The Chronicle of Pseudo- Yoshua the Stylite
(2000) in the prolific and invaluable Liverpool Uni-
versity Press Translated Texts for Historians series. 
up a box in which inhabitants could (and apparently did) place written grievances anonymously (ch. 29), and (a few years later) the response of Edessenes unhappy with the loutish behaviour of the local garrison - they wrote down their complaints on paper and posted them around the city in a successful attempt to embarrass their commander into action (ch. 96).

The Chronicle also records the governor sitting in one of the churches of Edessa every Friday where he settled lawsuits free of charge (ch. 29) - a practice clearly regarded as unusual behaviour, which highlights another important issue germane to the effectiveness of the law addressed by Harries - 'The Corrupt Judge' (ch. 8). She rightly draws attention to the pitfalls in trying to demonstrate, let alone quantify, the prevalence of judicial corruption in Late Antiquity, further arguing that 'while the potential for abuse of power was real, the opportunities available to late Roman iudices for misbehaviour were restricted by imperial, provincial and episcopal vigilance' ( 167 ). Yet there remains room for doubt about some aspects of this picture. Andronicus, the allegedly corrupt governor of Libya of whose case much is made here (I70-I), is not actually known to have been removed from office as a result of the Bishop Synesius' complaints to Constantinople. Moreover, even when allowance has been made for the role of rhetoric, invective, and personal axe-grinding in many of the sources which aver corruption, it remains incontrovertible that money played a recognized and officially sanctioned role in gaining access to late Roman officialdom. 'The question then becomes how best to make sense of this phenomenon; a plausible answer is to see it as an alternative strategy available to those unable to exploit ties of patronage and influence to achieve their (often legitimate) ends, well discussed by Christopher Kelly in CAH XIII (1998), 175-80. This is one area, too, where Harries' decision not to extend her discussion into the period covered by Justinian's Novels is unfortunate, for a number of them also raise this issue in the context of provincial litigants flooding Constantinople due, in part, to alleged judicial corruption. ${ }^{11}$

Honoré, too, broaches the subject of the efficacy of the late Roman legal system as part of a larger argument about the role of law in the survival of the East and the fragmentation of the West during the fifth century (23-9). He suggests that his conclusions in the body of the book about the greater degree of legal expertise on the part of eastern quaestors during the Theodosian dynasty compared with the West have far-reaching implications for the functioning of the legal system in the two halves of the Empire and so for their respective fates, but the case he presents in support of this scenario remains highly circumstantial and ultimately unpersuasive. While the initial counter-arguments he offers to Ramsay MacMullen's pessimistic views about the state of late Roman administration are cogent $(25-6)$, they do not differentiate between East and West, as his own larger argument requires - indeed, the string of evidence he cites from Augustine showing public confidence in the legal system (25) relates precisely to the West. The further discussion of the higher levels of eastern staff fines compared with western (26-8) may well reflect the greater economic prosperity of the East, but it is not made clear how this bears on his argument about the role of law in the survival of the East; it might even be used to argue that they were higher in the East because officials there were perhaps more susceptible to bribery. Priscus' famous exchange with a former Roman merchant resident in Attila's camp in A.D. 449 (not A.D. 440 - or 448 (Harries, 6)) about the inadequacies of the Roman legal system in the East (Priscus fr. II, 2 (Blockley) 11. 407-5IO), which has potentially damaging implications for his argument, is also dealt with rather too cursorily (29). He is right to emphasize the importance of effective tax collection (29), but the fundamental reason for the western government's increasingly inadequate financial resources during the fifth century lay in the progressive loss of vast tracts of revenue-yielding land to foreign invaders in Gaul, Spain, and (most critical of all) North Africa - a downward spiral from which it proved impossible to

11 Particularly Novels 8 and 80 , with discussion by E. Patlagean, Pauvreté économique et pauvreté sociale à Byzance $4^{e}-7^{e}$ siècles ( 1977 ), I 79-8r; cf. also C. Roue- ché, 'The functions of the governor in late antiquity: some observations', Antiquité tardive 6 (1998), 3 1-6. 
escape. I remain to be persuaded that the question of legal culture has a major bearing on this issue.

\section{THE IMPACT OF CHRISTIANITY}

The emperors whose laws were assembled in the Theodosian Code were, with the exception of Julian, avowed Christians, so it is natural that all three books should give some attention to the impact of this novel development on the aspects of Roman law which they consider. ${ }^{12}$ So far as the compilation of the Code itself is concerned, its chronological parameters have sometimes been seen as significant - Gibbon, for example, wrote of it being produced 'by the order of the younger Theodosius, to consecrate the laws of Christian princes from Constantine to his own reign'13 - as has the fact that legislation relating to the Church and the treatment of non-Christian groups was reserved for the sixteenth and final book. Matthews, however, challenges the 'natural and widely held assumption that this final book was intended as the culmination of the entire Theodosian Code; the moment at which the ideology and inheritance of Constantine's Christian empire was laid out for all to see' (I 20). He contrasts the 'Theodosian Code with Justinian's of a century later, in which these matters appear at the beginning of Book I, and sees this as symptomatic of 'a change of ideology that had not yet occurred at the time of the publication of the Theodosian Code' (290) ${ }^{14}$ There is much to be said for this, but it may have as much to do with the differing styles of the two emperors; both were well known for their piety and theological interests, but Justinian was undoubtedly the more forceful and interventionist in policymaking.

Honoré, on the other hand, gives Christianity a larger role in the genesis of the Code. 'Even if many or most lawyers were still pagan, the gradual fusion of these traditions [viz., legal learning and Christianity] is a key element in the movement for legal unity, reform and codification which issued in the Theodosian Code' (I 22). This claim emerges from another dimension of his stylometric analysis - namely, his attempt to identify, on the basis of the language used of Christianity in legislation, which quaestors were Christians. His conclusion is that, in parallel with growing legal expertise, increasing numbers of eastern quaestors were also Christians. This deduction, however, seems to me more problematic, dependent as it is on a comparatively limited range of expressions, some of which are (as he acknowledges) ambiguous and potentially dissembling (22-3). More importantly, however, his claims for the significance of this pattern in relation to the compilation of the Code (and indeed the survival of the Eastern Empire (in ch. I)) remain more a matter of assertion than demonstration.

By contrast, Harries makes a good case for the impact of Christianity on certain substantive aspects of late Roman legal practice. In ch. 7 ('Punishment'), she argues that 'Christianity's insistence on greater humanity in punishment' (135) resulted in important changes in practice and attitude. Executions by crucifixion and by being thrown to wild animals in the arena are no longer heard of after the fourth century, developments which she attributes at least in part to the influence of Christianity and whose significance she draws out effectively: the former was replaced by a more humane mode of execution, hanging ( 139 ), while the disappearance of the latter meant an end to criminals being used for public entertainment in the notorious 'fatal charades' of the Early Empire ( $5_{5}$ ). She also sets out evidence for bishops' 'articulate insistence on the

${ }^{12}$ For other important recent work in this area, see J. Beaucamp, Le Statut de la femme à Byzance $\left(4^{e}-7^{e}\right.$ siècles) (1990-92); D. Hunt, 'Christianising the Roman empire: the evidence of the Code', in Harries and Wood, The Theodosian Code, 143-58; J. Evans Grubbs, Law and Family in Late Antiquity: The Emperor Constantine's Marriage Legislation (1995); A. Arjava, Women and Law in Late Antiquity (1996).

${ }_{13}$ Decline and Fall, ch. 44 (vol. 2, 789 ).
${ }^{14}$ Harries does not discuss this issue in her book, but she has addressed it recently elsewhere, in 'How to make a law-code', in M. Austin et al. (eds), Modus Operandi: Essays in Honour of Geoffrey Rickman (1998), 63-78, making a similar case (I do not, however, understand the basis of her claim there (p. 66) that W. Turpin argues the Code is a Christian construct in $Z S S$ ro4 (1987), 620-30). 
values of compassion' ( ${ }^{52}$ ) as a constraining factor in the way officials dealt with the condemned. All of this serves as an invaluable counterpoint to the views of those who have portrayed Christianity as having an almost uniformly negative impact on the Late Empire and have emphasized the harshness of punishments in this period. ${ }^{15}$ Harries also investigates the repercussions of Christianity for late Roman law with reference to the development of the episcopalis audientia (ch.Io), showing how, from Constantine's far-reaching empowerment of bishops to hear legal disputes, their judicial role developed into something more akin to that of arbitrator or mediator. Here, as elsewhere, good use is made of papyrological evidence to provide a control on other sources and to counterbalance the superior generalities of legal pronouncements with a salutary sense of the realities and problems of ordinary life. ${ }^{16}$

It will be readily apparent that all three of these books deserve the close attention, not just of specialists in Roman law, but of anyone dealing with any aspect of the late Roman world on which the law impinged - which is to say most, if not all, of it. Matthews places the Theodosian Code firmly in its immediate historical context and provides a sure guide as to what can be deduced about the process of compilation and to those features for which historians must make due allowance in their use of it as an historical source. Honorés argument concerning the emergence of lawyer-quaestors adds an important dimension to our understanding of the genesis of the Code, whose character he also skilfully elucidates, even if his larger thesis about the role of legal culture in the divergent fates of East and West remains to be proved. Harries' book, the most wide-ranging and ambitious of the three, highlights a succession of important topics at the interface between law and political and social life in Late Antiquity, on which she challenges much received opinion and offers valuable alternative perspectives; she does not provide exhaustive treatments of these topics (nor does she claim to have done so), but she has laid out a stimulating agenda for much future work. As the Code aspired to do (NTh I.I), so also can these studies with justice cumulatively claim to have 'brought forth into the open and into clear light' numerous facets of late Roman law previously 'submerged in thick clouds of obscurity'. ${ }^{17}$

University of Wales, Lampeter

${ }^{15}$ Notably R. MacMullen, 'What difference did Christianity make?' and 'Judicial savagery in the Roman empire', both reprinted in his Changes in the Roman Empire (1990), chs 13 and 20.

$16 \mathrm{~J}$. Lamoreaux, 'Episcopal courts in late antiquity', $\not{F E C S} 3$ (1995), 143-67, absent from her bibliography, anticipates some of Harries' points and provides a useful supplement to her discussion. See also now the recently published volume edited by Ralph Mathisen, Law, Society, and Authority in Late Antiquity (2001), which includes three papers (by Noel Lenski, Leslie Dossey, and Harries herself) relating to episcopal involvement in the legal process, as well as much else of broader relevance to the subject matter of this review.

${ }_{17}$ In the same spirit, I note the following slips over matters of detail. Harries: on p. 24 it is implied that the commission for the first edition of the Justinianic Code was set up on 13 February 529, whereas it was actually 528; had it been the former, it would have completed its work in a mere seven weeks, which would have demonstrated not just 'great', but extra- ordinary, speed! a number of items cited in the notes are missing from the bibliography of secondary works: Mommsen (1905) (p. 14 n. 42); Voss (1982) (p. 42 nn. 16-17); Watson (1995b) (and by implication Watson (1995a)) (p. 142 n. 53); Dewing (1934) (p. 182 n. 55). Honoré: Const. Haec was of course issued in 528 , not 538 (p. I 47 n. 270); at p. 249 l. 4, read 'Aquileia' for 'Thessalonica'. Matthews: in Const. Tanta 23 the completion of the Digest is not connected with victory over Persia (p. 30 n. 69), but with the conclusion of the so-called 'Eternal Peace' (532), as its wording makes clear ("bella Parthica abolita sunt et quieti perpetua tradita'); for the years after 437 , the Justinianic Code drew on more than just 'the Novellae of Theodosius II and his successors down to Anthemius, together with some laws of the first years of the reign of Justinian himself' (90): as Appendix I to the Corpus Iuris Civilis vol. 2 (pp. 507-8) shows, it includes a significant number of laws of other emperors from the late fifth and early sixth centuries (e.g., Anastasius); ch. $7 \mathrm{n} .56$ does not refer to an oration of Libanius, as claimed at p. $28 \mathrm{I} \mathbf{n}$. I. 